\title{
The Effect of Dried Grape Pomace Feeding on Nutrients Digestibility and Serum Biochemical Profile of Wethers
}

\author{
Miroslav Juráček ${ }^{1} \mathbb{D}$, Patrícia Vašeková ${ }^{1}$, Peter Massányi ${ }^{2} \mathbb{D}$, Anton Kováčik ${ }^{2} \mathbb{D}$, Daniel Bíro ${ }^{1}$, Milan Šimko $^{1}$, \\ Branislav Gálik ${ }^{1}\left(\mathbb{D}\right.$, Michal Rolinec ${ }^{1}\left(\mathbb{D}\right.$, Ondrej Hanušovský ${ }^{1, *(\mathbb{D})}$, Renata Kolláthová ${ }^{1}$, Eva Mixtajová ${ }^{1}$ \\ and Mária Kalúzová ${ }^{1}$
}

Citation: Juráček, M.; Vašeková, P.; Massányi, P.; Kováčik, A.; Bíro, D.; Šimko, M.; Gálik, B.; Rolinec, M.; Hanušovský, O.; Kolláthová, R.; et al. The Effect of Dried Grape Pomace Feeding on Nutrients Digestibility and Serum Biochemical Profile of Wethers. Agriculture 2021, 11, 1194. https://doi.org/10.3390/ agriculture11121194

Academic Editors: Lubomira Gresakova and Emilio Sabia

Received: 19 October 2021

Accepted: 25 November 2021

Published: 26 November 2021

Publisher's Note: MDPI stays neutral with regard to jurisdictional claims in published maps and institutional affiliations.

Copyright: (c) 2021 by the authors. Licensee MDPI, Basel, Switzerland. This article is an open access article distributed under the terms and conditions of the Creative Commons Attribution (CC BY) license (https:/ / creativecommons.org/licenses/by/ $4.0 /)$.
1 Department of Animal Nutrition, Institute of Nutrition and Genomics, Slovak University of Agriculture in Nitra, Trieda A. Hlinku 2, 94976 Nitra, Slovakia; miroslav.juracek@uniag.sk (M.J.); vasekovap@gmail.com (P.V.); daniel.biro@uniag.sk (D.B.); milan.simko@uniag.sk (M.Š.); branislav.galik@uniag.sk (B.G.); michal.rolinec@uniag.sk (M.R.); xkollathova@uniag.sk (R.K.); xmixtajova@uniag.sk (E.M.); xkaluzova@uniag.sk (M.K.)

2 Department of Animal Physiology, Institute of Applied Biology, Slovak University of Agriculture in Nitra, Trieda A. Hlinku 2, 94976 Nitra, Slovakia; peter.massanyi@uniag.sk (P.M.); anton.kovacik@uniag.sk (A.K.)

* Correspondence: ondrej.hanusovsky@uniag.sk

\begin{abstract}
The aim of this study was to find the effect of dried grape pomace (GP) feeding on the nutrients digestibility coefficients and biochemical parameters of sheep blood serum. The experiment was divided into three feeding periods-C (control), GP1 (1\% grape pomace concentration), and GP2 ( $2 \%$ grape pomace concentration). Wethers in three groups in balance cages were housed for right feces collection. The $\mathrm{C}$ feed diet consisted of hay, ground wheat, soybean meal, mineral and vitamin lick. An experimental diet with $1 \%$ and $2 \%$ addition of GP from the daily dry matter intake was fed. After that, digestibility coefficients (in \%) were calculated by the difference between nutrient intake and excretion. Furthermore, in the wethers' blood, biochemical parameters (mineral, energetic, nitrogen, and enzymatic profile) were analyzed. After the GP2 feeding, statistically significant higher digestibility of CP (crude protein), NFC (nonfiber carbohydrates), NDF (neutral detergent fiber), and OM (organic matter) was found. However, the addition of dried GP increased significantly the content of $\mathrm{Cl}^{-}$and decreased the value of glucose, nevertheless, their concentrations were within the reference interval. Parameters of the wethers' blood serum nitrogen and enzymatic profile were not affected by GP feeding. Dried grape pomace in an amount of $2 \%$ diet dry matter can be considered a suitable source of nutrients in sheep feeding, which in addition should improve the digestibility of diet crude protein.
\end{abstract}

Keywords: biochemical parameters; grape by-products; nutrition; sheep; utilization

\section{Introduction}

The wine industry produces annually millions of tons of grape by-products, which are valuable resources of biologically active substances that have many potential uses, also in animal nutrition [1]. Grape pomace (GP) is a by-product from the wine industry and represents about $15-20 \%$ of the weight of the grape bunch [2]. The GP is a suitable feed additive for animal nutrition [3-8]. The product can be fed fresh, dried, or ensiled [9]. The nutritive value of grape pomace is variable depending on the grape-growing region, cultivar, technology of winemaking, and the proportion of seeds and pulp [10-12]. The GP is a source of health benefits: flavonoids with antioxidant and anti-inflammatory activity [13-15] that can improve rumen fermentation [16] and delay gas production [17]. Digestibility of crude protein, organic matter, and NDF (neutral detergent fiber) was increased in sheep receiving GP $[18,19]$. Many studies have focused on the biochemical profile of small ruminant's 
blood with impact on the effect of breed, age, gender, location, and season [20-24]. The effect of different dosages of GP on biochemical parameters of ruminants' blood in different experiments was realized in dairy cows [25], in calves [26], or in sheep [27]. Our previous studies have analyzed the effects of various natural substances obtained as by-products of agricultural production on animal nutrient digestibility, health status, or reproductive efficiency [28-34]. These studies indicate the great potential of these products for use in animal nutrition, however, the GP addition in animal feeding has to be further examined. The hypothesis is that GP addition to the ruminants' daily diet will increase the nutrients digestibility without the negative effect on the animals' health. Based on the above, the aim of this study was to describe the effect of dried GP feeding on the nutrients digestibility coefficients and blood serum biochemical parameters of wethers.

\section{Materials and Methods}

\subsection{The Materials Animals and Housing}

Experiments were conducted at the Experimental Center of Livestock at the Department of Animal Husbandry (Slovak University of Agriculture in Nitra). The wethers were of Ile de France breed, obtained from the University farm in Kolinany (Slovak University of Agriculture in Nitra) with an average weight of $34.05 \pm 1.97 \mathrm{~kg}$ and age of 4 months. The study consisted of 3 groups: control-C, $1 \%$ grape pomace-GP1, and $2 \%$ grape pomace-GP2 (Table 1). During the preparatory time period, wethers were free housed in group without bedding in pens. Then, the wethers were housed in balance cages individually to monitor proper individual daily diet intake and feces collection in the balance period. The experiment complied with animal health care standards. The animals were under veterinary control and cared for by experienced animal caretakers during the whole experiment. The routine manipulation with animals during the experiment did not cause disproportionate and excessive stress. The conditions of animal care, manipulations, and use corresponded with the instructions of the Ethics Committee of the Slovak University of Agriculture in Nitra, Protocol No. 48/2013.

Table 1. Experiment scheme.

\begin{tabular}{llll}
\hline Control & & Grape Pomace Addition \\
\hline $\mathbf{C}(\boldsymbol{n}=\mathbf{8})$ & & GP1 $(n=8)$ GP2 $(n=8)$ & \\
\hline $\begin{array}{l}\text { Preparatory period } \\
14 \text { days }\end{array}$ & Balance period & Preparatory period & Balance period \\
\hline
\end{tabular}

C—control group, GP 1—grape pomace 1\% from daily dry matter intake, GP 2—grape pomace $2 \%$ from daily dry matter intake.

\subsection{Feeding and Experimental Design}

The composition of experimental and control daily diets are listed in Table 2. Grape pomace of the Pinot Gris variety (Vitis vinifera L.) was obtained from the academic vinery (Slovak University of Agriculture in Nitra). The nutrient content of feed components is shown in Table 3. During the whole experiment, animals were fed two times per day. Half of the daily diet was fed during the morning and another $50 \%$ was fed during the afternoon. Water, mineral and vitamin lick was accessible ad libitum. The concentration of biologically active substances (total polyphenols: $27.38 \pm 1.38 \mathrm{mg} \mathrm{GAE} / \mathrm{g}$-equivalent of gallic acid) was determined in a previous study [35]. The control (C) daily diet from meadow hay, ground wheat, soybean meal, and mineral and vitamin lick was formed. The preparatory period before $C$ diet feeding was 14 days (Table 1). Following this, the experimental balance period lasted 5 days. Daily diet GP1 and GP2 consisted of meadow hay, ground wheat, soybean meal, mineral and vitamin lick, and dried GP (1 and 2\% of daily dry matter intake, respectively). The preparatory period before experimental variant GP1 and GP2 lasted 7 days and the balance period 5 days. The difference between the experimental variants was only in the concentrations of dried GP in the diet. 
Table 2. Feed rations used in the digestibility experiment.

\begin{tabular}{llll}
\hline \multirow{2}{*}{ Feeds (g) } & \multicolumn{2}{l}{ Feeding Groups } & \\
\cline { 2 - 4 } & C & GP1 & GP2 \\
\hline Meadow hay & 700.0 & 700.0 & 700.0 \\
Ground wheat & 118.6 & 118.6 & 118.6 \\
Soybean meal & 238.6 & 238.6 & 238.6 \\
Grape pomace (dried) & - & $10.3^{*}$ & $20.6^{* *}$ \\
Mineral and vitamin lick & ad libitum & ad libitum & ad libitum \\
\hline
\end{tabular}

* $1 \%$ from daily dry matter intake, ${ }^{* *} 2 \%$ from daily dry matter intake, mineral and vitamin lick (Jan Valasek, Ludrova, Slovakia) content was as follows: $\mathrm{MnO}$ (as Mn) $3100 \mathrm{mg}$, $\mathrm{ZnO}$ (as Zn) $4800 \mathrm{mg}, \mathrm{Ca}\left(\mathrm{IO}_{3}\right)_{2}$ (as I) $125 \mathrm{mg}$, Se $31 \mathrm{mg}, \mathrm{CoSO}_{4} .7 \mathrm{H}_{2} \mathrm{O}$ (as Co) $42 \mathrm{mg}$, vit. A 300,000 i.u., vit. D3 125,000 i.u., vit. E $100 \mathrm{mg}$, ash 95\%, Ca 9.9\%, $\mathrm{P} 5.0 \%$, Na $13.7 \%$, Mg $5.1 \%$ in $1 \mathrm{~kg}$ of dry matter.

Table 3. Chemical composition of feed components.

\begin{tabular}{lllll}
\hline & Meadow Hay & Wheat & Soybean Meal & Grape Pomace \\
\hline $\mathrm{DM}^{*}$ & 873.85 & 909.75 & 898.95 & 942.25 \\
$\mathrm{CP}$ & 69.12 & 125.86 & 484.85 & 98.70 \\
$\mathrm{EE}$ & 10.41 & 17.29 & 15.52 & 84.19 \\
$\mathrm{CF}$ & 388.29 & 31.55 & 52.04 & 183.98 \\
$\mathrm{ADF}$ & 459.15 & 43.56 & 103.9 & 380.87 \\
$\mathrm{NDF}$ & 697.17 & 116.77 & 117.03 & 459.67 \\
$\mathrm{NFE}$ & 478.45 & 805.79 & 377.89 & 593.42 \\
$\mathrm{NFC}$ & 169.56 & 720.57 & 312.89 & 317.72 \\
$\mathrm{OM}$ & 946.26 & 980.49 & 930.28 & 960.28 \\
$\mathrm{Ash}$ & 53.74 & 19.51 & 69.72 & 39.72 \\
$\mathrm{Ca}$ & 4.58 & 0.40 & 3.39 & 4.46 \\
$\mathrm{P}$ & 2.28 & 4.29 & 7.70 & 3.21 \\
$\mathrm{Mg}$ & 1.52 & 1.45 & 3.65 & 1.20 \\
$\mathrm{Na}$ & 0.30 & 0.20 & 0.30 & 0.26 \\
$\mathrm{~K}$ & 12.82 & 5.07 & 24.86 & 12.89 \\
\hline
\end{tabular}

DM: dry matter, CP: crude protein, EE: ether extract, CF: crude fiber, ADF: acid detergent fiber, NDF: neutral detergent fiber, NFE: nitrogen free extract, NFC: nonfiber carbohydrates, OM: organic matter, ${ }^{*}$ in $\mathrm{g} / \mathrm{kg}$ of original matter, other nutrients in $\mathrm{g} / \mathrm{kg}$ of dry matter.

\subsection{Blood Sampling and Analyses}

Blood samples were collected from vena jugularis externa on the morning of the last day of the nutrition balance experiment in each variant. Sampling and analysis of blood were realized. For biochemical analysis of blood serum blood samples were centrifuged at $1006 \times \mathrm{g}$ for $30 \mathrm{~min}$. Potassium $(\mathrm{K})$, sodium $(\mathrm{Na})$, and chloride $(\mathrm{Cl})$ ions were analyzed by an EasyLite analyzer (Medica, Bedford, MA, USA) with an ion-selective electrode [36,37]. Blood serum concentrations of calcium $(\mathrm{Ca})$, magnesium $(\mathrm{Mg})$, phosphorus $(\mathrm{P})$, triglycerides (TG), cholesterol (CHOL), glucose (GLU), total protein (TP), urea, albumin (ALB), aspartate aminotransferase (AST), alanine aminotransferase (ALT), alkaline phosphatase (ALP), gamma glutamyl transferase (GGT), were determined using DiaSys (Diagnostic Systems GmbH, Holzheim, Germany) kits on the Randox RX Monza analyzer (Randox Laboratories, Crumlin, UK) [37,38]. Globulin (GLB) was calculated mathematically by subtracting the serum levels of albumins from serum total proteins [32].

\subsection{Feed and Feces Collection, Analysis and Determination of Digestibility}

During the balance period once daily in the morning the rests and samples of feeds, daily diets, and feces were collected. The content of organic and inorganic nutrients was analyzed in the rests and samples of feeds and in pooled samples of feces for each animal for 5 days. Dry matter content (DM) was analyzed by gravimetric method at $103^{\circ} \mathrm{C}$, crude protein $(\mathrm{CP})$ by Kjeldahl method, ether extract (EE) by gravimetric method according to the Soxhlet principle, crude fiber $(\mathrm{CF})$ by gravimetric method as a residue insoluble in 
acid and alkaline media after deduction of ash (Fibertec System, Tecator), acid detergent fiber (ADF) by gravimetric method as a residue after hydrolysis in acid detergent solution (Fibertec System, Tecator), neutral detergent fiber (NDF) by gravimetric method as a residue after hydrolysis in neutral detergent solution (Fibertec System, Tecator) and ash (A) by gravimetric method at $550{ }^{\circ} \mathrm{C}$ (muffle furnace) were determined. The content of organic matter (OM), nitrogen free extract (NFE), and nonfiber carbohydrates (NFC) were calculated according to formulas:

$$
\begin{gathered}
\mathrm{OM}=\mathrm{DM}-\mathrm{A}(\mathrm{g} / \mathrm{kg}) \\
\mathrm{NFE}=\mathrm{DM}-(\mathrm{CP}+\mathrm{EE}+\mathrm{CF}+\mathrm{A})(\mathrm{g} / \mathrm{kg}) \\
\mathrm{NFC}=\mathrm{DM}-(\mathrm{CP}+\mathrm{EE}+\mathrm{NDF}+\mathrm{A})(\mathrm{g} / \mathrm{kg})
\end{gathered}
$$

The content of $\mathrm{Ca}, \mathrm{Mg}, \mathrm{Na}, \mathrm{K}$ was determined by High Resolution Continuum Source Atomic Absorption Spectrometer contrAA 700 (ANALYTIC JENA, Jena, Germany) and content of P by 6400 Spectrophotometer (JENWAY, Montreal, QC, Canada). In vivo apparent digestibility coefficients of $\mathrm{CP}, \mathrm{EE}, \mathrm{CF}, \mathrm{NFE}, \mathrm{NFC}, \mathrm{OM}, \mathrm{ADF}$, and NDF in the diets (in \%) were calculated as:

In vivo digestibility coefficient $=[($ nutrient intake - nutrient excreted $) /$ nutrient intake $] \times 100(\%)$

\subsection{Statistical Analysis}

Statistical evaluation of results by IBM SPSS v26.0 was realized. For calculation of basic statistical characteristics (mean and standard deviation), determination of the significance of differences and comparison of the results between the control and experimental diets within the variables (Tukey Test). One-way ANOVA was performed at the level $p<0.05$.

\section{Results and Discussion}

\subsection{Nutrient Digestibility}

The apparent digestibility of crude protein was affected by dried grape pomace addition (Table 4). In the control group (C) a significantly lower digestibility coefficient of crude protein $(p<0.05)$, compared to the GP1 and GP2 was observed. This result corresponds with findings that were reported by some authors $[18,19]$. According to Guerra-Rivas et al. [11] the diet fed to the sheep (control vs. grape pomace) had minor effects on ruminal degradation parameters of crude protein. Ishida et al. [39] found lower digestibility of crude protein of grape pomace in comparison to the control diet $(65.69$ vs. $75.14 \%)$. It can be assumed that this was due to a higher proportion of grape pomace from dry matter intake ( $24 \%$ from dry matter intake of wethers). This trend was also confirmed by Abarghuei et al. [40] and Jayanegara et al. [41]. Differences in the digestibility of other nutrients between the control and experimental group GP1 were not significant. However, the apparent digestibility of nonfiber carbohydrates (NFC), organic matter $(\mathrm{OM})$, and neutral detergent fiber (NDF) of the diets significantly $(p<0.05)$ increased by higher dose of dried grape pomace (C vs. GP2; NFC $p=0.018 ; \mathrm{OM} p=0.022$; NDF $p=0.015$ ). This trend of increasing the digestibility of organic matter and NDF, with an increase in their intake, was also confirmed by Bahrami et al. [42] and Foiklang et al. [16]. On the contrary, Baumgartel et al. [43] observed decreasing nutrient digestibility between basal and test diet including grape pomace. After the addition of GP to the ruminants' diets, higher OM digestibility was found [44]. 
Table 4. Digestibility coefficients (\%) of the different feeding groups.

\begin{tabular}{|c|c|c|c|}
\hline & \multicolumn{3}{|c|}{ Feeding Groups } \\
\hline & $\mathrm{C}$ & GP1 & GP2 \\
\hline $\mathrm{CP}$ & $70.22^{a} \pm 1.19$ & $72.17^{b} \pm 1.46$ & $73.49^{b} \pm 0.98$ \\
\hline $\mathrm{EE}$ & $58.10 \pm 3.45$ & $63.03 \pm 0.58$ & $60.76 \pm 2.69$ \\
\hline $\mathrm{CF}$ & $47.25 \pm 4.04$ & $50.25 \pm 1.94$ & $51.30 \pm 1.14$ \\
\hline NFE & $67.31 \pm 2.30$ & $66.91 \pm 1.44$ & $69.85 \pm 0.51$ \\
\hline NFC & $77.52^{\mathrm{a}} \pm 1.07$ & $77.78^{a} \pm 1.58$ & $79.93^{b} \pm 0.16$ \\
\hline $\mathrm{OM}$ & $62.32^{\mathrm{a}} \pm 2.83$ & $62.93^{a} \pm 0.53$ & $65.09^{b} \pm 0.62$ \\
\hline ADF & $49.49 \pm 3.04$ & $50.36 \pm 0.24$ & $51.37 \pm 1.01$ \\
\hline NDF & $49.91^{\mathrm{a}} \pm 3.83$ & $51.40^{\mathrm{a}} \pm 0.53$ & $53.97^{b} \pm 1.19$ \\
\hline
\end{tabular}

C: control, GP1: $1 \%$ addition of dried grape pomace from daily dry matter intake (DMI), GP2: $2 \%$ addition of dried grape pomace from daily DMI, CP: crude protein, EE: ether extract, CF: crude fiber, NFE: nitrogen free extract, NFC: nonfiber carbohydrates, OM: organic matter, ADF: acid detergent fiber, NDF: neutral detergent fiber. Different letters in row indicate statistical differences (Tukey test, $p<0.05$ ); data are presented as mean \pm SD.

\subsection{Mineral Profile}

The changes in feeding are manifested in blood serum mineral profile [45]. Minerals perform a number of important physiological functions, such as the effect on acid-base balance, osmotic pressure, adrenal function, normal heart function, but also the metabolism of proteins or carbohydrates [46-48]. The difference in the P content after the GP was not statistically significant (Table 5). However, average P concentrations were higher than the upper limits in comparison as previously reported [48-51]. On the other hand, Jelinek et al. [52] found in rams similar blood serum P content from 2.49 to $2.92 \mathrm{mmol} / \mathrm{L}$ (depending on age). Identically, Chedea et al. [25] did not describe a statistically significant effect of dried GP (15\% concentrations) in dairy cows on blood serum P content. The Ca content was similar, after feeding of all examined diets and in the interval according to Merck [51] (2.88-3.20 mmol/L). Ca concentrations were also comparable with data reported by Dias et al. [20] and Kovacik et al. [37], but higher in comparison with Schweinzer et al. [53]. Similarly, Chedea et al. [25] reported an effect of dried GP on Ca content in dairy cows (diet contained 15\% dried GP). Iannaccone et al. [26] also reported in Fresian calves (10\% proportion of dried GP meal in concentrate) a significant effect on the content of Ca. A similar ratio of Ca:P 1.07:1 (C, GP1) and 1.13:1 (GP2) was found which is in consent with previously reported data [48]. Concentrations of $\mathrm{Mg}$ in experimental groups were higher than upper limits $1.10 \mathrm{mmol} / \mathrm{L}$ found by Tschuor et al. [50] and $1.31 \mathrm{mmol} / \mathrm{L}$ Merck [51]. Simpraga et al. [21] determined the content of $\mathrm{Mg} 1.30-1.60 \mathrm{mmol} / \mathrm{L}$, which was similar to GP2. The GP addition did not affect the content of $\mathrm{Mg}$, which was also confirmed by Chedea et al. [25]. The $\mathrm{Na}^{+}$content was after the addition of GP lower in comparison with control variant but its content was in the interval $130.00-155.00 \mathrm{mmol} / \mathrm{L}$ reported by Vrzgula et al. [48]. However, the analyzed $\mathrm{Na}^{+}$values were lower than determined by Kovacik et al. [37]. The intake of GP decreased non-significantly the $\mathrm{K}^{+}$content. According to Merck [51], the reference range for $\mathrm{K}^{+}$is $3.90-5.40 \mathrm{mmol} / \mathrm{L}$. The values found in our experiment were in the range reported by Tschour et al. [50] $(4.60-6.50 \mathrm{mmol} / \mathrm{L})$. The ratio of $\mathrm{Na}$ and K 23.81:1 (C), 24.04:1 (GP1), 26.53:1 (GP2) was found, thus similar compared to the recommendation of Vrzgula et al. [48]. The 2\% GP intake increased the concentrations of $\mathrm{Cl}^{-}(p<0.05)$, which we do not consider a negative effect, because the main problem for chlorides is mainly a decrease, which can cause digestive disorders [48]. However, in all groups, the $\mathrm{Cl}^{-}$concentrations in blood serum were in physiological range according to Vrzgula et al. [48] and Tschour et al. [50], but higher compared to Merck [51]. Kovacik et al. [37] found higher concentrations of $\mathrm{Cl}^{-}$compared in their study. The main factor that can influence the reduced mineral absorption in this type of dietary supplement is increased fiber intake [54], which is not confirmed by animals' in vivo studies, similar to our study. 
Table 5. Biochemical wether blood parameters.

\begin{tabular}{lllll}
\hline & & Feeding Groups & \\
\hline Parameters & Unit & C & GP1 & GP2 \\
\hline $\mathrm{P}$ & $\mathrm{mmol} / \mathrm{L}$ & $2.89 \pm 0.18$ & $2.87 \pm 0.16$ & $2.75 \pm 0.50$ \\
$\mathrm{Ca}$ & $\mathrm{mmol} / \mathrm{L}$ & $3.09 \pm 1.12$ & $3.08 \pm 0.42$ & $3.10 \pm 0.77$ \\
$\mathrm{Mg}$ & $\mathrm{mmol} / \mathrm{L}$ & $1.69 \pm 0.92$ & $1.92 \pm 0.96$ & $1.32 \pm 0.44$ \\
$\mathrm{Na}$ & $\mathrm{mmol} / \mathrm{L}$ & $143.08 \pm 2.96$ & $135.13 \pm 8.18$ & $140.63 \pm 1.96$ \\
$\mathrm{~K}$ & $\mathrm{mmol} / \mathrm{L}$ & $6.01 \pm 1.16$ & $5.62 \pm 0.33$ & $5.30 \pm 0.06$ \\
$\mathrm{Cl}$ & $\mathrm{mmol} / \mathrm{L}$ & $105.28^{\mathrm{a}} \pm 1.68$ & $106.60^{\mathrm{a}} \pm 0.91$ & $108.40^{\mathrm{b}} \pm 1.47$ \\
$\mathrm{GLU}$ & $\mathrm{mmol} / \mathrm{L}$ & $3.90^{\mathrm{a}} \pm 0.30$ & $3.17^{\mathrm{b}} \pm 1.05$ & $3.26^{\mathrm{b}} \pm 0.35$ \\
$\mathrm{CHOL}$ & $\mathrm{mmol} / \mathrm{L}$ & $1.01 \pm 0.00$ & $1.01 \pm 0.00$ & $1.01 \pm 0.00$ \\
$\mathrm{TG}$ & $\mathrm{mmol} / \mathrm{L}$ & $0.45 \pm 0.06$ & $0.53 \pm 0.08$ & $0.43 \pm 0.07$ \\
$\mathrm{TP}$ & $\mathrm{g} / \mathrm{L}$ & $74.45 \pm 8.18$ & $77.25 \pm 6.01$ & $66.25 \pm 15.35$ \\
$\mathrm{ALB}$ & $\mathrm{g} / \mathrm{L}$ & $33.87 \pm 3.43$ & $23.34 \pm 10.15$ & $29.41 \pm 6.39$ \\
$\mathrm{GLB}$ & $\mathrm{g} / \mathrm{L}$ & $40.83 \pm 9.44$ & $53.91 \pm 12.97$ & $46.50 \pm 10.64$ \\
$\mathrm{UREA}$ & $\mathrm{mmol} / \mathrm{L}$ & $6.36 \pm 1.19$ & $6.52 \pm 0.86$ & $5.63 \pm 0.75$ \\
$\mathrm{AST}$ & $\mu \mathrm{kat} / \mathrm{L}$ & $2.02 \pm 0.79$ & $1.26 \pm 0.69$ & $1.57 \pm 0.28$ \\
$\mathrm{ALT}$ & $\mu \mathrm{kat} / \mathrm{L}$ & $0.34 \pm 0.14$ & $0.40 \pm 0.08$ & $0.41 \pm 0.04$ \\
$\mathrm{ALP}$ & $\mu \mathrm{kat} / \mathrm{L}$ & $3.49 \pm 1.51$ & $4.34 \pm 1.24$ & $5.16 \pm 1.37$ \\
$\mathrm{GGT}$ & $\mu \mathrm{kat} / \mathrm{L}$ & $0.14 \pm 0.08$ & $0.20 \pm 0.09$ & $0.17 \pm 0.06$ \\
\hline
\end{tabular}

C: control, GP1: $1 \%$ addition of dried grape pomace from daily dry matter intake (DMI), GP2: $2 \%$ addition of dried grape pomace from daily DMI, GLU: glucose, CHOL: cholesterol, TG: triglycerides, TP: total protein, ALB: albumins, GLB: globulins, AST: aspartate aminotransferase, ALT: alanine aminotransferase, ALP: alkaline phosphatase, GGT: gamma glutamyl transferase, different letters in row indicate statistical differences (Tukey test, $p<0.05)$; data are presented as mean $\pm \mathrm{SD}$.

\subsection{Energetic Profile}

The glucose values (Table 5) were in physiological range $2.30-4.44 \mathrm{mmol} / \mathrm{L}[48,50,51]$. However, glucose value decreased after the addition of GP (1\% GP by $18.72 \% ; 2 \%$ GP by $16.41 \%)$, but statistically significant $(p<0.05)$ only in GP2, that was also confirmed by Iannaccone et al. [26]. The concentrations of $1 \%$ GP also non-significantly decreased glucose concentration in an experiment of Chedea et al. [25] and Kollathova et al. [8]. The decrease in glucose is probably related to the low energy value of GP [10]. Decreased glucose content is also associated with liver damage $[48,55]$, which in our case can be refuted based on the results of liver enzymes. On the other hand, Alba et al. [27] determined statistically higher blood glucose after the addition of grape residue flour ( $2 \%$ from concentrate) in lactating dairy sheep compared to a recent study. The cholesterol concentrations in the wethers' blood serum were in all groups very similar. Bahrami and Chekani-Azar [42] and Alba et al. [27] found no statistically significant differences in cholesterol concentrations after GP feeding. Slightly lower cholesterol values in blood serum compared to physiological range ([49]: $1.05 \mathrm{mmol} / \mathrm{L}$ ) were found. In addition to antioxidant activity, polyphenols have been shown to have several cardioprotective and atheroprotective effects, including lowering plasma cholesterol levels [26]. The concentration of triacylglycerides (TG) in GP2 was the highest but statistically non-significant. Similar results were also reported by Chedea et al. [25], where GP feeding has not affected the values of triacylgylcerides. On the other hand, Alba et al. [27] after feeding grape pomace confirmed a statistically significant increase in TG in dairy sheep as a consequence of increased fat intake from grape pomace.

\subsection{Nitrogen Profile}

Changes in protein, albumin, and urea levels are needed to diagnose disorders of nitrogen metabolism [48]. The highest but statistically non-significant content of total proteins $(p=0.380)$, globulin $(p=0.548)$, and urea $(p=0.564)$ in GP1 was found (Table 5). However, in the control, the highest albumin content was observed but statistically nonsignificant $(p=0.154)$. After the GP addition, a narrower ratio between albumin and globulin (C 0.83/1; GP1 0.43/1; GP2 0.63/1) was observed. Alba et al. [27] reported statistically significant lower TP, GLB, and urea after grape residue flour ( $2 \%$ from concentrate) 
addition in lactating dairy sheep in comparison with the present study. Alba et al. [27] also determined similar results after GP feeding on albumin (statistically non-significant). Bahrami and Chekani-Azar [42] found no significant effect of GP on the content of total proteins. The concentration of total proteins, albumin, globulin, and urea were in the reference range [21,56]. In contrast to our results, Panev et al. [57], Carlos et al. [58], and Jelinek et al. [59] reported lower average total proteins in wethers, in Morada Nova sheep, as well as generally in sheep.

\subsection{Enzymatic Profile}

Enzymatic profile indicators (AST, ALT, ALP) (Table 5) were in physiological range according to Tschour et al. [50]. Determination of enzyme activity is necessary in order to exclude hepatopathy. Furthermore, AST and ALT values were comparable with Rahman et al. [60]. The GGT values were under the limit recommended by Tschour et al. [50], Lepherd et al. [61], and Shek Vugrovecki et al. [24], but in accordance with reference values according to Al-Hadithy et al. [62]. After the GP feeding non-significant lower AST $(p=0.512)$ values and higher ALT $(p=0.490), \operatorname{ALP}(p=0.124)$ and GGT $(p=0.857)$ values were observed. Similarly, Chedea et al. [25] did not confirm the effect of GP feeding in dairy cows (diet contained 15\% dried GP) on AST, ALP, and GGT. Iannaccone et al. [26] also did not find the effect of GP addition in calves (10\% dried GP meal in concentrate) on AST and ALT values. In the study of Nudda et al. [63] the effect of grape seeds addition (300 g per day) on sheep AST and ALT parameters was not found but statistically significant higher ALP and lower GGT were observed. Comparable with the present study, a decrease in AST values in the lambs after feeding of GP $(5 \%, 10 \%$, and $20 \%$ in dry matter) with the lowest value in variant with $5 \%$ addition, was reported by Jin et al. [64].

\section{Conclusions}

The GP addition to the ruminants' daily diet increased the digestibility of nutrients without the negative effect on the biochemical profile of animals. The digestibility of crude protein, NFC, NDF, and OM in wethers was significantly higher at a higher dose of dried grape pomace ( $2 \%$ of GP). The addition of GP into the daily diet did not affect the nitrogen, enzymatic, mineral, and energetic profile of wethers blood serum except $\mathrm{Cl}^{-}$and glucose ( $2 \%$ of GP). Dried grape pomace in an amount of $2 \%$ diet dry matter can be considered as a suitable source of nutrients in sheep feeding, which in addition should improve the digestibility of diet crude protein.

Author Contributions: Conceptualization, M.R., D.B. and B.G.; data curation, O.H. and E.M.; formal analysis, M.K.; funding acquisition, B.G.; investigation, M.R., P.V. and R.K.; methodology, M.R. and M.J.; project administration, B.G.; resources, B.G.; software, O.H. and E.M.; supervision, M.Š., P.M. and A.K.; validation, D.B., M.K. and B.G.; visualization, M.J. and M.R.; writing-original draft, M.J., O.H. and E.M.; writing-review and editing, D.B., M.Š. and M.J. All authors have read and agreed to the published version of the manuscript.

Funding: This research and APC were funded by the Slovak Research and Development Agency, grant number APVV-16-0170 (by-products from grape processing as a bioactive substance source in animal nutrition).

Institutional Review Board Statement: The conditions of animal care, manipulations and use corresponded with the instructions of the Ethics Committee of the Slovak University of Agriculture in Nitra, Protocol No. 48/2013. According to the State Veterinary and Food Administration of the Slovak Republic, the given study is evaluated as inexperienced agricultural practices that do not fall under the legislation of Government Regulation of the Slovak Republic 377/2012 of 14 November 2012, laying down requirements for the protection of animals used for scientific or educational purposes.

Informed Consent Statement: Not applicable.

Data Availability Statement: The data presented in this study are available on request from the corresponding author. 
Conflicts of Interest: The authors declare no conflict of interest. The funders had no role in the design of the study; in the collection, analyses, or interpretation of data; in the writing of the manuscript, or in the decision to publish the results.

\section{References}

1. Domínguez, J.; Martínez-Cordeiro, H.; Lores, M. Earthworms and grape marc: Simultaneous production of a high-quality biofertilizer and bioactive-rich seeds. In Grape and Wine Biotechnology; Morata, A., Loira, I., Eds.; Intech: London, UK, 2016; pp. 167-183.

2. Bordiga, M.; Travaglia, F.; Locatelli, M. Valorisation of Grape Pomace: An Approach That Is Increasingly Reaching Its Maturity-A Review. Int. J. Food Sci. Technol. 2019, 54, 933-942. [CrossRef]

3. Yan, L.; Kim, I. Effect of Dietary Grape Pomace Fermented by Saccharomyces Boulardii on the Growth Performance, Nutrient Digestibility and Meat Quality in Finishing Pigs. Asian-Australas. J. Anim. Sci. 2011, 24, 1763-1770. [CrossRef]

4. Eleonora, N.; Dobrei, A.; Alina, D.; Bampidis, V.; Valeria, C. Grape Pomace in Sheep and Dairy Cows Feeding. J. Hortic. For. Biotechnol. 2014, 18, 146-150.

5. Abarghuei, M.; Rouzbehan, Y.; Alipour, D. The Effect of Tannins in Grape Pomace and Oak Leaf on the in Vitro Organic Matter Digestibility and in Situ Disappearance of Sheep. Iran. J. Appl. Anim. Sci. 2015, 5, 95-103.

6. Lichovnikova, M.; Kalhotka, L.; Adam, V.; Klejdus, B.; Anderle, V. The Effects of Red Grape Pomace Inclusion in Grower Diet on Amino Acid Digestibility, Intestinal Microflora, and Sera and Liver Antioxidant Activity in Broilers. Turk. J. Vet. Anim. Sci. 2015, 39, 406-412. [CrossRef]

7. Nudda, A.; Buffa, G.; Atzori, A.; Cappai, M.; Caboni, P.; Fais, G.; Pulina, G. Small Amounts of Agro-Industrial Byproducts in Dairy Ewes Diets Affects Milk Production Traits and Hematological Parameters. Anim. Feed Sci. Technol. 2019, $251,76-85$. [CrossRef]

8. Kolláthová, R.; Gálik, B.; Halo, M.; Kováčik, A.; Hanušovský, O.; Bíro, D.; Rolinec, M.; Juráček, M.; Šimko, M. The Effects of Dried Grape Pomace Supplementation on Biochemical Blood Serum Indicators and Digestibility of Nutrients in Horses. Czech J. Anim. Sci. 2020, 65, 58-65. [CrossRef]

9. Pirmohammadi, R.; Golgasemgarebagh, A.; Azari, A.M. Effects of Ensiling and Drying of White Grape Pomace on Chemical Composition, Degradability and Digestibility for Ruminants. J. Anim. Vet. Adv. 2007, 6, 1079-1082.

10. Winkler, A.; Weber, F.; Ringseis, R.; Eder, K.; Dusel, G. Determination of Polyphenol and Crude Nutrient Content and Nutrient Digestibility of Dried and Ensiled White and Red Grape Pomace Cultivars. Arch. Anim. Nutr. 2015, 69, 187-200. [CrossRef]

11. Guerra-Rivas, C.; Gallardo, B.; Mantecón, Á.R.; del Álamo-Sanza, M.; Manso, T. Evaluation of Grape Pomace from Red Wine By-Product as Feed for Sheep. J. Sci. Food Agric. 2017, 97, 1885-1893. [CrossRef]

12. Kalli, E.; Lappa, I.; Bouchagier, P.; Tarantilis, P.A.; Skotti, E. Novel Application and Industrial Exploitation of Winery By-Products. Bioresour. Bioproc. 2018, 5, 1-21. [CrossRef]

13. Brindza, J.; Ivanisova, E.; Grygorieva, O.; Abrahamova, V.; Schubertova, Z.; Abrahamova, V. Antioxidants from Plants in Human Nutrition and Improving of Health. Acupunct. Nat. Med. 2015, 2, 40.

14. Kerasioti, E.; Terzopoulou, Z.; Komini, O.; Kafantaris, I.; Makri, S.; Stagos, D.; Gerasopoulos, K.; Anisimov, N.Y.; Tsatsakis, A.M.; Kouretas, D. Tissue Specific Effects of Feeds Supplemented with Grape Pomace or Olive Oil Mill Wastewater on Detoxification Enzymes in Sheep. Toxicol. Rep. 2017, 4, 364-372. [CrossRef] [PubMed]

15. Zhao, J.; Li, Q.; Zhang, R.; Liu, W.; Ren, Y.; Zhang, C.; Zhang, J. Effect of Dietary Grape Pomace on Growth Performance, Meat Quality and Antioxidant Activity in Ram Lambs. Anim. Feed Sci. Technol. 2018, 236, 76-85. [CrossRef]

16. Foiklang, S.; Wanapat, M.; Norrapoke, T. Influence of Grape Pomace Powder as a Feed Supplement on Feed Intake, Digestibility and Rumen Ecology of Dairy Steers. Khon Kaen Agric. J. 2016, 44, 147-154.

17. Sinz, S.; Kunz, C.; Liesegang, A.; Braun, U.; Marquardt, S.; Soliva, C.R.; Kreuzer, M. In Vitro Bioactivity of Various Pure Flavonoids in Ruminal Fermentation, with Special Reference to Methane Formation. Czech J. Anim. Sci. 2018, 63, $293-304$.

18. Alipour, D.; Rouzbehan, Y. Effects of Several Levels of Extracted Tannin from Grape Pomace on Intestinal Digestibility of Soybean Meal. Livest. Sci. 2010, 128, 87-91. [CrossRef]

19. Bahrami, Y.; Foroozandeh, A.-D.; Zamani, F.; Modarresi, M.; Eghbal-Saeid, S.; Chekani-Azar, S. Effect of Diet with Varying Levels of Dried Grape Pomace on Dry Matter Digestibility and Growth Performance of Male Lambs. J. Anim. Plant Sci. 2010, 6, 605-610.

20. Dias, I.R.; Viegas, C.A.; Silva, A.; Pereira, H.; Sousa, C.; Carvalho, P.; Cabrita, A.; Fontes, P.J.; Silva, S.; Azevedo, J.M.T.D. Haematological and Biochemical Parameters in Churra-Da-Terra-Quente Ewes from the Northeast of Portugal. Arq. Bras. De Med. Veterinária E Zootec. 2010, 62, 265-272. [CrossRef]

21. Šimpraga, M.; Šmuc, T.; Matanović, K.; Radin, L.; Shek-Vugrovečki, A.; Ljubičić, I.; Vojta, A. Reference Intervals for Organically Raised Sheep: Effects of Breed, Location and Season on Hematological and Biochemical Parameters. Small Rumin. Res. 2013, 112, 1-6. [CrossRef]

22. Bhat, S.A.; Mir, M.R.; Reshi, A.A.; Ahmad, S.B.; Husain, I.; Bashir, S.; Khan, H.M. Impact of Age and Gender on Some Blood Biochemical Parameters of Apparently Healthy Small Ruminants of Sheep and Goats in Kashmir Valley India. Int. J. Agric. Sci. Vet. Med. 2014, 2, 22-27.

23. Lipińska, P.; Atanasov, A.G.; Palka, M.; Jóźwik, A. Chokeberry Pomace as a Determinant of Antioxidant Parameters Assayed in Blood and Liver Tissue of Polish Merino and Wrzosówka Lambs. Molecules 2017, 22, 1461. [CrossRef] 
24. Shek Vugrovečki, A.; Vojta, A.; Šimpraga, M. Establishing Reference Intervals for Haematological and Biochemical Blood Variables in Lika Pramenka Sheep. Vet. Arh. 2017, 87, 487-499. [CrossRef]

25. Chedea, V.S.; Pelmus, R.S.; Lazar, C.; Pistol, G.C.; Calin, L.G.; Toma, S.M.; Dragomir, C.; Taranu, I. Effects of a Diet Containing Dried Grape Pomace on Blood Metabolites and Milk Composition of Dairy Cows. J. Sci. Food Agric. 2017, 97, 2516-2523. [CrossRef]

26. Iannaccone, M.; Elgendy, R.; Giantin, M.; Martino, C.; Giansante, D.; Ianni, A.; Dacasto, M.; Martino, G. RNA Sequencing-Based Whole-Transcriptome Analysis of Friesian Cattle Fed with Grape Pomace-Supplemented Diet. Animals 2018, 8, 188. [CrossRef] [PubMed]

27. Alba, D.F.; Campigotto, G.; Cazarotto, C.J.; Dos Santos, D.S.; Gebert, R.R.; Reis, J.H.; Souza, C.F.; Baldissera, M.D.; Gindri, A.L.; Kempka, A.P.; et al. Use of Grape Residue Flour in Lactating Dairy Sheep in Heat Stress: Effects on Health, Milk Production and Quality. J. Therm. Biol. 2019, 82, 197-205. [CrossRef] [PubMed]

28. Gálik, B.; Bíro, D.; Marko, H.; Juráček, M.; Šimko, M.; Vaščáková, V.; Rolinec, M. The Effect of Phytoadditives on Macroelements Digestibility of Sport Horses. J. Cent. Eur. Agric. 2011, 12, 390-397. [CrossRef]

29. Šimko, M.; Čerešňáková, Z.; Bíro, D.; Juráček, M.; Gálik, B.; Straková, E.; France, J.; Alzahal, O.; McBride, B. Influence of Wheat and Maize Starch on Fermentation in the Rumen, Duodenal Nutrient Flow and Nutrient Digestibility. Acta Vet. Brno 2011, 79, 533-541. [CrossRef]

30. Rolinec, M.; Bíro, D.; Gálik, B.; Šimko, M.; Juráček, M. Effect of Phytoadditives on Sow Reproductive Efficiency. J. Microbiol. Biotechnol. Food Sci. 2021, 2021, 1907-1914.

31. Gálik, B.; Bíro, D.; Šimko, M.; Juráček, M.; Capcarová, M.; Kolesárová, A.; Rolinec, M.; Toman, R.; Kanka, T. The Effect of Dietary Bee Pollen Intake on Growth Performance and Biochemical Indicators of Rats. Acta Vet. Brno 2016, 85, 99-104. [CrossRef]

32. Kovacik, A.; Gasparovic, M.; Tvrda, E.; Tokarova, K.; Kovacikova, E.; Rolinec, M.; Rumanova, L.; Capcarova, M.; Galik, B. Effects of Humic Acid Diet on the Serum Biochemistry and Oxidative Status Markers in Pheasants. Veterinární Med. 2020, 65, 258-268. [CrossRef]

33. Dupak, R.; Kovac, J.; Kalafova, A.; Kovacik, A.; Tokarova, K.; Hascik, P.; Simonova, N.; Kacaniova, M.; Mellen, M.; Capcarova, M. Supplementation of Grape Pomace in Broiler Chickens Diets and Its Effect on Body Weight, Lipid Profile, Antioxidant Status and Serum Biochemistry. Biologia 2021, 76, 2511-2518. [CrossRef]

34. Rolinec, M.; Bíro, D.; Šimko, M.; Juráček, M.; Hanušovskỳ, O.; Schubertová, Z.; Chadimová, L.; Gálik, B. Grape Pomace Ingestion by Dry Cows Does Not Affect the Colostrum Nutrient and Fatty Acid Composition. Animals 2021, 11, 1633. [CrossRef] [PubMed]

35. Vašeková, P.; Juráček, M.; Bíro, D.; Šimko, M.; Gálik, B.; Rolinec, M.; Hanušovskỳ, O.; Kolláthová, R.; Ivanišová, E. Bioactive Compounds and Fatty Acid Profile of Grape Pomace. Acta Fytotechn. Zootech. 2020, 23, 230-235. [CrossRef]

36. Massanyi, P.; Stawarz, R.; Halo, M.; Formicki, G.; Lukac, N.; Cupka, P.; Schwarcz, P.; Kovacik, A.; Tusimova, E.; Kovacik, J. Blood Concentration of Copper, Cadmium, Zinc and Lead in Horses and Its Relation to Hematological and Biochemical Parameters. J. Environ. Sci. Health Part A 2014, 49, 973-979. [CrossRef]

37. Kovacik, A.; Arvay, J.; Tusimova, E.; Harangozo, L.; Tvrda, E.; Zbynovska, K.; Cupka, P.; Andrascikova, S.; Tomas, J.; Massanyi, P. Seasonal Variations in the Blood Concentration of Selected Heavy Metals in Sheep and Their Effects on the Biochemical and Hematological Parameters. Chemosphere 2017, 168, 365-371. [CrossRef] [PubMed]

38. Kovacik, A.; Tvrda, E.; Miskeje, M.; Arvay, J.; Tomka, M.; Zbynovska, K.; Andreji, J.; Hleba, L.; Kovacikova, E.; Fik, M.; et al. Trace Metals in the Freshwater Fish Cyprinus Carpio: Effect to Serum Biochemistry and Oxidative Status Markers. Biol. Trace Elem. Res. 2019, 188, 494-507. [CrossRef] [PubMed]

39. Ishida, K.; Kishi, Y.; Oishi, K.; Hirooka, H.; Kumagai, H. Effects of Feeding Polyphenol-Rich Winery Wastes on Digestibility, Nitrogen Utilization, Ruminal Fermentation, Antioxidant Status and Oxidative Stress in Wethers. Anim. Sci. J. 2015, 86, 260-269. [CrossRef]

40. Abarghuei, M.; Rouzbehan, Y.; Alipour, D. The Influence of the Grape Pomace on the Ruminal Parameters of Sheep. Livest. Sci. 2010, 132, 73-79. [CrossRef]

41. Jayanegara, A.; Leiber, F.; Kreuzer, M. Meta-Analysis of the Relationship between Dietary Tannin Level and Methane Formation in Ruminants from in Vivo and in Vitro Experiments. J. Anim. Physiol. Anim. Nutr. 2012, 96, 365-375. [CrossRef]

42. Bahrami, Y.; Chekani-Azar, S. Some Blood Biochemical Parameters and Yield of Lambs Fed Ration Contained Dried Grape Pomace. Glob. Vet. 2010, 4, 571-575.

43. Baumgärtel, T.; Kluth, H.; Epperlein, K.; Rodehutscord, M. A Note on Digestibility and Energy Value for Sheep of Different Grape Pomace. Small Rumin. Res. 2007, 67, 302-306. [CrossRef]

44. Tayengwa, T.; Chikwanha, O.C.; Raffrenato, E.; Dugan, M.E.; Mutsvangwa, T.; Mapiye, C. Comparative Effects of Feeding Citrus Pulp and Grape Pomace on Nutrient Digestibility and Utilization in Steers. Animal 2021, 15, 100020. [CrossRef]

45. Pavlata, L.; Misurova, L.; Pechova, A.; Husakova, T.; Dvorak, R. Direct and Indirect Assessment of Selenium Status in Sheep-a Comparison. Veterinární Med. 2012, 57, 219-223. [CrossRef]

46. James, L.F. Serum Electrolyte, Acid-Base Balance, and Enzyme Changes in Acute Halogeton Glomeratus Poisoning in Sheep. Can. J. Comp. Med. 1968, 32, 539. [PubMed]

47. Persson, J.; Luthman, J. The Effects of Insulin, Glucose and Catecholamines on Some Blood Minerals in Sheep. Acta Vet. Scand. 1974, 15, 519-532. [CrossRef] [PubMed] 
48. Vrzgula, L.; Alijev, A.A.; Bartko, P.; Bouda, J.; Dvorak, R.; Gabrasanski, P.; Illek, J.; Jagos, P.; Karsai, F.; Kona, E.; et al. Metabolic Disorders and Their Prevention in Farm Animals, 2nd ed.; Priroda: Bratislava, Slovak, 1990.

49. Jackson, P.; Cockcroft, P. Clinical Examination of the Udder. Clinical Examination of Farm Animals, 1st ed.; Blackwell Science: Hoboken, NJ, USA, 2002; pp. 154-166.

50. Tschuor, A.C.; Riond, B.; Braun, U.; Lutz, H. Hämatologische Und Klinisch-Chemische Referenzwerte Für Adulte Ziegen Und Schafe. Schweiz. Arch. Für Tierheilkd. 2008, 150, 287-295. [CrossRef] [PubMed]

51. Manual, M.V. Hematologic Reference Ranges-Appendixes. Merck Sharp Dohme Kenilworth. 2019. Available online: http://www. merckvetmanual.com (accessed on 29 June 2019).

52. Jelinek, P.; Helanova, I.; Illek, J.; Frais, Z. Biochemical and Hematological Values of the Blood in Rams during Rearing [Nutrition, Age]. Acta Vet. 1984, 53, 143-150. [CrossRef]

53. Schweinzer, V.; Iwersen, M.; Drillich, M.; Wittek, T.; Tichy, A.; Mueller, A.; Krametter-Froetscher, R. Macromineral and Trace Element Supply in Sheep and Goats in Austria. Vet. Med. 2017, 62, 62-73. [CrossRef]

54. Baye, K.; Guyot, J.-P.; Mouquet-Rivier, C. The Unresolved Role of Dietary Fibers on Mineral Absorption. Crit. Rev. Food Sci. Nutr. 2017, 57, 949-957. [CrossRef] [PubMed]

55. Jing, X.; Wang, W.; Degen, A.; Guo, Y.; Kang, J.; Liu, P.; Ding, L.; Shang, Z.; Zhou, J.; Long, R. Energy Substrate Metabolism in Skeletal Muscle and Liver When Consuming Diets of Different Energy Levels: Comparison between Tibetan and Small-Tailed Han Sheep. Animal 2021, 15, 100162. [CrossRef] [PubMed]

56. Slanina, L.; Sokol, J.; Augustinsky, V.; Bajova, V.; Balascak, J.; Balun, J.; Bartik, M.; Benes, J.; Beseda, I.; Birova, V.; et al. Vademecum of a Veterinarian; Príroda: Bratislava, Slovakia, 1991.

57. Panev, A.; Hauptmanová, K.; Pavlata, L.; Pechová, A.; Filípek, J.; Dvorak, R. Effect of Supplementation of Various Selenium Forms and Doses on Selected Parameters of Ruminal Fluid and Blood in Sheep. Czech J. Anim. Sci. 2013, 58, 37-46. [CrossRef]

58. Carlos, M.; Leite, J.; Chaves, D.; Vale, A.; Façanha, D.; Melo, M.; Soto-Blanco, B. Blood Parameters in the Morada Nova Sheep: Influence of Age, Sex and Body Condition Score. J. Anim. Plant Sci. 2015, 25, 950-955.

59. Jelínek, P.; Koudela, K.; Doskocil, J.; Illek, J.; Kotrbacek, V.; Kovaru, F.; Kroupova, V.; Kucera, M.; Kudlac, E. Farm Animal Physiology; Mendel University in Brno: Brno, Czech Republic, 2003.

60. Rahman, M.K.; Islam, S.; Ferdous, J.; Uddin, M.H.; Hossain, M.B.; Hassan, M.M.; Islam, A. Determination of Hematological and Serum Biochemical Reference Values for Indigenous Sheep (Ovies aries) in Dhaka and Chittagong Districts of Bangladesh. Vet. World 2018, 11, 1089-1093. [CrossRef]

61. Lepherd, M.; Canfield, P.; Hunt, G.B.; Bosward, K. Haematological, Biochemical and Selected Acute Phase Protein Reference Intervals for Weaned Female Merino Lambs. Aust. Vet. J. 2009, 87, 5-11. [CrossRef] [PubMed]

62. Al-Hadithy, H. Estimation of Serum Liver Enzymes Activities in Awassi Sheep. Iraqi J. Vet. Med. 2013, 37, 115-120. [CrossRef]

63. Nudda, A.; Correddu, F.; Marzano, A.; Battacone, G.; Nicolussi, P.; Bonelli, P.; Pulina, G. Effects of Diets Containing Grape Seed, Linseed, or Both on Milk Production Traits, Liver and Kidney Activities, and Immunity of Lactating Dairy Ewes. J. Dairy Sci. 2015, 98, 1157-1166. [CrossRef]

64. Jin, Y.; Hao, S.; Zhao, J.; Ma, X.; Su, R.; Ren, Y.; Zhang, C.H.; Zhang, J. Effect of Dietary Grape Pomace on Growth Performance, Organ Index and Blood Biochemical Indexes in Sheep. China Anim. Husb. Vet. Med. 2016, 43, 2326-2332. 